\title{
Development of Healthcare Waste Management in Serbia and Challenges in the Improvement of the Quality of Healthcare Services
}

VERICA S. JOVANOVIĆ, Institute of Public Health of Serbia "Dr Milan Jovanović Batut", Belgrade

Review paper

JAN B. GERRIT TESINK, COWI, Denmark

DRAGOMIR V. JOVANOVIĆ, University Clinic of Gynecology

and Obstetric "Narodni front", Belgrade

NELA Ž. ĐONOVIĆ, University of Kragujevac,

Faculty of Medical Sciences, Kragujevac

MARIJA R. JEVTIĆ, University of Novi Sad,

Faculty of Medicine, Novi Sad

BRANISLAVA I. MATIĆ, Institute of Public Health of Serbia

"Dr Milan Jovanović Batut", Belgrade

RADMILA M. ŠEROVIĆ, Ministry of Energy, Development and

Environmental Protection of Republic of Serbia, Belgrade

Proper Healthcare Waste Management (HCWM) was introduced in the Republic of Serbia in 2007 with the support of the European Union. Since then, the amounts of waste treated, prior to landfill, have steadily increased and more and more healthcare institutions adopted HCWM systems. In parallel large numbers of healthcare workers were trained in proper HCWM. This study quantifies the progress made.

The study analysed the period 2009 to 2012 using three methods of data collection.

On basis of data collected, it has been established that with a population of just over seven million, Serbia generates between 4,500 and 5,000 tonnes of infectious waste on an annual basis of which some $20 \%$ originates from the treatment of out-patients, $75 \%$ from the treatment of in-patients and $5 \%$ from micro-biological laboratory tests. While in 2009 only one third of this waste was treated prior to disposal, this fraction has increased to two thirds in 2011. The data also show that more than $90 \%$ of healthcare facilities have developed individual healthcare waste management plans up from less than $20 \%$ in 2009. In every healthcare facility there are at least 2 people trained in healthcare waste management, and in total there are approximately 3000 staff members who received formal HCWM training provided through the Institute for Public Health.

Healthcare waste management is continuously improving in the Republic of Serbia and is well established in more than $85 \%$ of healthcare facilities. There are still issues to be improved especially regarding treatment on healthcare waste other than infectious waste.

Key words: Healthcare, Healthcare waste management, infectious medical waste

\section{INTRODUCTION}

Proper Healthcare Waste Management (HCWM) was introduced in the Republic of Serbia in 2007 with

Author's addres: Verica Jovanović, Institute of Public Health of Serbia, "Dr Milan Jovanović Batut", Belgrade, Dr Subotića 5

Paper received:26.12.2013.

Paper accepted: 12.02.2014. the support of the European Union. Weak healthcare waste management system was a prominent problem in the Republic of Serbia until 2007. Untreated healthcare waste was disposed of together with municipal waste in improperly organised and operated landfills. At the time, very few engineered landfills were available in the Republic of Serbia. Infectious and sharp healthcare waste represented a serious threat to hospital staff handling waste; individuals working on the landfills, as well as animals digging through the 
waste. Since then, the amounts of waste treated, prior to disposal on landfills, have steadily increased and more and more healthcare institutions introduced proper HCWM systems. Proper management of infectious healthcare waste was the first field of HCWM to be introduced in Serbia $[1,2]$. Concurrently, large numbers of healthcare workers were trained in proper HCWM. Two technical assistance EU funded projects have been implemented in Serbia, with the second one still in progress. HCWM training has been implemented in healthcare and veterinary sectors, at first with projects' support and later through special training programs conducted by the Institute of Public Health of Serbia 'Dr Milan Jovanovic Batut' and Veterinary chamber [5, 6]

In a needs assessment conducted in the human healthcare sector, an urgent need for a well organised healthcare waste management system was identified, enabling each healthcare institution producing healthcare waste to segregate, treat and appropriately dispose of healthcare waste $[3,4]$. Newly defined healthcare waste management system was introduced from 2007 till 2009, complying with the relevant legislation, the Law on Environmental Protection and Law on Protection of Contagious Diseases in the Republic of Serbia. Newly established HCWM was in line with Serbian National Strategy on waste and EC cooperation strategies in terms of public health and environmental protection.

The first EU funded project was named "Technical Assistance for Healthcare Waste Management" and this project developed a basis of proper infectious HCWM in the healthcare sector, in cooperation with the Ministry of Health (MoH), the Ministry of Environmental Protection (MoESP) at the time and the Veterinary Directorate. This first technical initiative directly targeted 55 healthcare institutions (hospitals, primary healthcare centres and public health institutes) and provided support by supplying autoclaves, which were delivered to institutions in all 25 administrative districts. All of these institutions were in need of an organised and safe health waste management system. In parallel, the Ministry of Health and Ministry of Environmental Protection were provided support in drafting the appropriate by-laws on Healthcare Waste Management and on Pharmaceutical Waste. In this way, the project managed to touch upon the priority needs of all the key healthcare waste producers and initiate the implementation of the necessary changes.

In 2009, the Law on Waste Management was adopted in the Republic of Serbia, and it is currently in effect. In 2010, the MoH and MoESP adopted a new by-law named Rulebook on Healthcare Waste Management. This is still the key regulation of the
Republic of Serbia concerning healthcare waste management and these two legal acts define the basis for the organised and proper healthcare waste management in the Republic of Serbia. The second project, still in progress, is the ongoing EU funded project named "Technical Assistance for the Treatment of Healthcare Waste in Serbia". This project provides technical support to the above mentioned Ministries in order to strengthen the established HCWM system in Serbia. Apart from its objective to reinforce the infectious healthcare waste treatment in Serbia, this project is also tackling the management of other hazardous healthcare waste streams.

In this study, the progress made in the Republic of Serbia, with regards to healthcare waste management in the human healthcare sector is quantified.

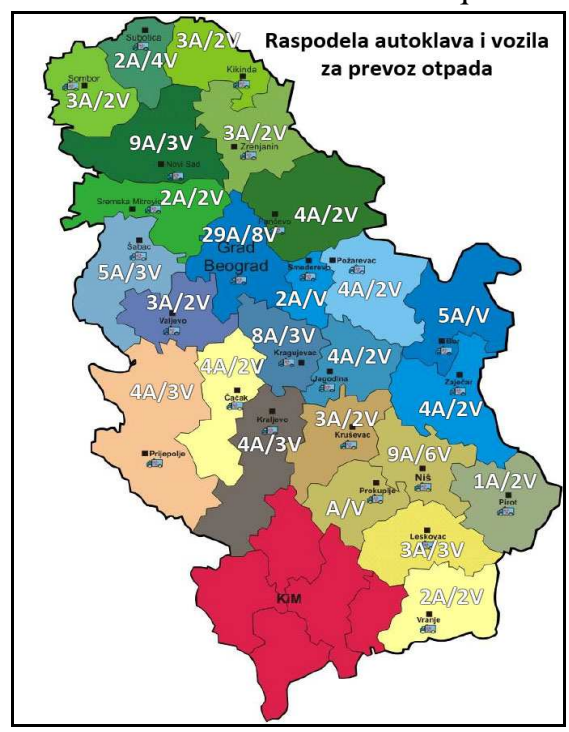

Figure 1 - Infectious waste treatment unit in the Republic of Serbia (A-autoclave, $V$-vehicle)

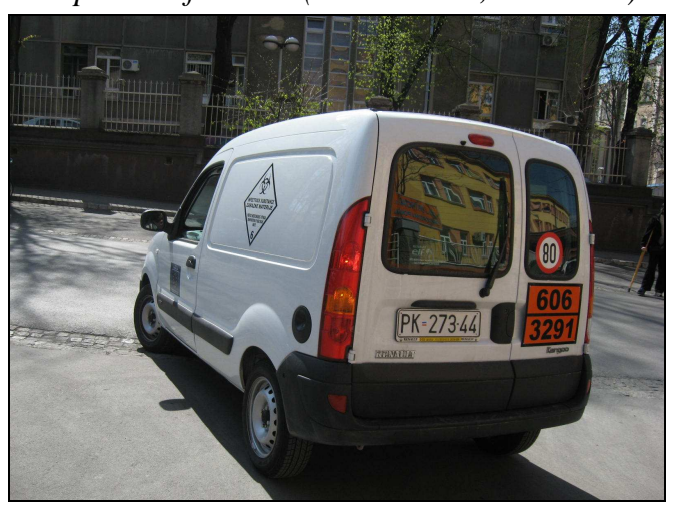

Figure 2 - Transport of Infectious Waste in the Republic of Serbia

\section{METHODS AND DATA COLLECTION}

The study analyzed the period 2009 to 2012 in the public healthcare sector in the Republic of Serbia 
using three methods of data collection. Random sampling design was used to obtain the list of healthcare facilities in which the study was conducted. These included health centers, general hospitals, special hospitals, clinical centers, institutes, and institutes of public health. All healthcare facilities in public healthcare sector of Serbia were listed. During random sampling each health facility was selected depending on the type of healthcare facility as well as level of healthcare services provided in the republic healthcare system. The study was conducted in a total of 250 healthcare facilities selected from the public network of healthcare facilities in 25 administrative districts of the Republic of Serbia.

This cross-sectional study investigated HCWM in healthcare facilities, all over Serbia, at all three levels of healthcare services provision- primary level healthcare institutions called Health centers, secondary healthcare institutions called general hospitals and tertiary level healthcare institutions called Clinical Centers and Clinical Hospital Centers. The sample for the first research was composed of 250 different healthcare facilities which were chosen randomly. The results were supplemented with data from the data base of the Institute for Public Health of Serbia "Dr Milan Jovanovic Batut". Data base on healthcare waste management including treatment of infectious healthcare waste from healthcare institutions from overall Serbia was established by Ministry of health Program of general interests called "Monitoring of healthcare waste management in the Republic of Serbia" in 2009. This program was conducted by Institute of Public Health of the Republic of Serbia. Through subsequent data analysis and extrapolation baseline data for Serbia as a whole were established.

The second data source was formed by data gathered from the expert's audit or direct observations.

The third data source was from the repeated research conducted by the same questionnaire sent to the same healthcare institutions as during the first research. Again results from this repeated research (active data collection) were supplemented with data from the data IPH of Serbia data base (passive data collection).

As part of the above described research process a questionnaire which was used for the research was developed for the assessment of practices of HCWM in 2009. Finally developments during the years 2010 to 2012 were measured through active and passive data collection. Active data collection involved repeated questionnaires, the same one sent to the same healthcare institutions as the original sample as well as by monitoring visits to 45 individual healthcare institutions. Questioners have been sent again to 250 hea- lthcare institutions. Filled questioners have been collected afterwards, evaluated and findings have been analyzed. Questioners have been filled in both researches by persons responsible for healthcare waste management from approached healthcare facilities. The main research instrument - Questioner was consists of five sections with all in all 80 questions. Sections were related to general data about the healthcare facilities including data on healthcare services and waste generation in general, about healthcare waste streams, equipment for treatment of infectious waste, human resources for HCWM, and financing of HCWM. Questioner was pretested before adoption of its final version. In both cases the data collected from the research were supplemented with data from the data base of the Institute for Public Health of Serbia of the Republic of Serbia.

The third source of data was gained from expert's reports from visits to healthcare facilities and their monitoring on HCWM. Monitoring visits have been conducted in 45 healthcare facilities in human healthcare sector. For that purpose an instrument was used called Control check list for the assessment of HCWM in visited healthcare institutions. Better understanding of the HCWM in healthcare institutions was reached by all three sources of data after their analyses.

The numeric data collected from the selected health facilities in the republic of Serbia districs was compiled using the Microsoft Excel computer software. Then data was coded using the numbers 1 and $0 . \mathrm{Nu}-$ mber 1 implies the presence of a particular item and 0 the absence of such item/category. The coded items were summed up to provide the frequencies and the percentage was calculated using MS Excel and SPSS software.

\section{RESULTS}

On basis of data collected, it has been concluded that with a population of just over seven millions, Serbia generates between 4,500 and 5,000 tonnes of infectious waste on an annual basis in the public healthcare sector. $20 \%$ of these quantities of infectious waste were originated from the treatment of out-patients, $75 \%$ from the treatment of in-patients and 5\% from micro-biological laboratory tests.

The Institute for Public Health "Dr Milan Jovanovic Batut" is collecting data on infectious waste generation and treatment from the Central Treatment Points (CTPs) and Local Treatment Points (LTPs). On the basis of these data approximate waste generation rates per out-patient visit, per bed day and per micro-biological test can be determined. The data are presented in the table 1 (data on generation rate of infectious waste). 
Table 1. Healthcare waste generation rates

\begin{tabular}{|l|l|l|}
\hline Occurrence & amount & unit \\
\hline Out-patient visit & 0.01 & $\mathrm{Kg} / \mathrm{visit}$ \\
\hline Waste generation in Prim. HCF & 12 & $\mathrm{Kg} /$ day \\
\hline In patient treatment & 0.26 & $\mathrm{Kg} /$ bed.day \\
\hline Micro-biological test & 0.004 to 0.4 & $\mathrm{Kg} /$ test \\
\hline Waste generation in micro-biology & From 250 to 14,000 & $\mathrm{Kg}$ per laboratory per year \\
\hline
\end{tabular}

While in 2009 only one third of this waste was treated prior to disposal, this fraction has increased to two thirds in 2011. The data also show that more than $90 \%$ of healthcare facilities have developed individual healthcare waste management plans up from less than $20 \%$ in 2009.

Not included in the above data, is liquid waste generated in operating theatres. During operations, body liquids are removed by a suction system and collected in glass bottles. After the operation the liquids are disposed of into the sewer system and the bottles clean and sterilised for re-use. With a typical amount of 2 litres per operation, the total amount of this type of liquid waste generated in operating theatres in Serbia can be estimated to be in the order of 500.000 litre per year. It should be noted however that only a small percentage of patients operated has to be considered as infectious.

In every healthcare facility there are at least 2 people trained in healthcare waste management, and in total there are approximately 3000 staff members who received formal HCWM training, provided through the Institute for Public Health. At the end of 2009 there were above 1700 healthcare workers trained in HCWM.

The Government of Serbia, with the support of their partners, has embarked on the development and improvement of a sound HCWM system. Within this framework, a number of initiatives has been taken including two the EU supported projects.

The Law on Waste Management classifies all pharmaceutical waste as hazardous and states that all pharmaceutical waste shall be treated as hazardous waste while the Rulebook on HCWM distinguishes non-hazardous pharmaceutical waste, potentially hazardous pharmaceutical waste and hazardous pharmaceutical waste.

The results of the questionnaire show significant differences between the types of HCFs. With one exception, primary HCFs report lower accumulated pharmaceutical waste amounts than health centres and general and special hospitals. Clinic Centers typically report the largest amounts of accumulated pharmaceutical waste and Institutes for Public Health the lowest. An overview of these figures is provided in the table below.

Table 2. Average waste generation by Healthcare Institutions

\begin{tabular}{|l|l|l|}
\hline \multicolumn{1}{|c|}{ Healthcare Facility } & \multicolumn{1}{|c|}{$\begin{array}{c}\text { Average reported pharmaceutical waste } \\
\text { generation }\end{array}$} & \multicolumn{1}{c|}{ Comments } \\
\hline Primary Health Centre & $20 \mathrm{~kg} / \mathrm{yr}$ & $\begin{array}{l}\text { Excluding one centre reporting more than } \\
54,000 \mathrm{~kg}\end{array}$ \\
\hline Special Institutes & $20 \mathrm{~kg} / \mathrm{yr}$ & \\
\hline Health Centres & $25 \mathrm{~kg} / \mathrm{yr}$ & \\
\hline General and Special Hospitals & $25 \mathrm{~kg} / \mathrm{yr}$ & Clinical centres and clinical hospitals \\
\hline Clinical Centres & $100 \mathrm{~kg} / \mathrm{yr}$ & $\begin{array}{l}\text { Consultants estimate, only one IPH } \\
\text { returned usable data: } 0.02 \mathrm{~kg}\end{array}$ \\
\hline IPHs & $1 \mathrm{~kg} / \mathrm{yr}$ & \\
\hline
\end{tabular}

Within pharmacies, current generation rates of pharmaceutical waste are limited as well. More and more pharmacies apply good practices in the procurement and distribution of drugs and contracts for the supply of drugs typically include clauses making it obligatory for suppliers to take back and replace drugs that have a remaining shelf time of one month or less. As result generation rates are typically in the range of several kilograms per pharmacy rather that in the range of tonnes. Based in information provided by 18 public pharmacies which reported a total annual generation of 40 kilograms of pharmaceutical waste, the total annual amount for all 33 public pharmacies is estimated to be less than 100 kilograms. Combined public and private pharmacies will generate about 500 $\mathrm{kg}$ of pharmaceutical waste per year.

The total amount of chemical waste reported by the 70 institutions is well above 100 tonnes per year with photochemical waste being the largest waste stream with 55 tonnes reported by 32 institutions. For Serbia as a whole, the generation rate of photo-chemicals can be estimated to be in the order of 350 to 450 tonnes per year. 


\section{CONCLUSION}

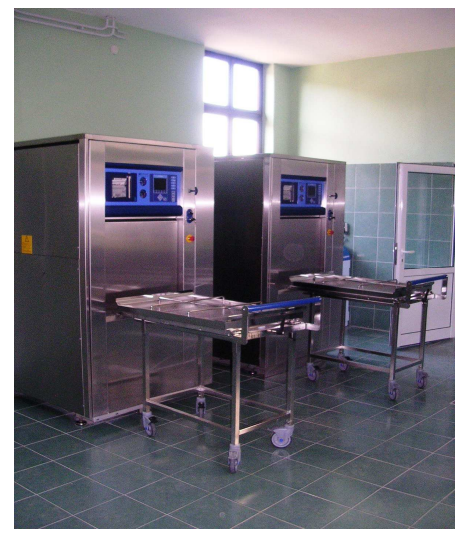

Figure 3 - Autoclaves for the sterilization of infectious waste

Healthcare waste management is continuously improving in the Republic of Serbia and is well established in more than $85 \%$ of healthcare facilities.

The Government of Serbia, with the support of their partners, has embarked on the development and improvement of a sound HCWM system. Within this framework, a number of initiatives has been taken in the Republic of Serbia including EU supported CARDS project "Technical Assistance for Health Care Waste Management", and EU supported IPA project "Technical assistance for Treatment of Healthcare Waste in Serbia". Delivery of the equipment for the sterilization of infectious healthcare waste was implemented by two particular supply contracts financed by EU from 2007 till 2011. The mentioned initiatives have established a solid basis for environmentally sound HCWM with a network of Central Treatment (CTPs) and Local Treatment Points (LTPs). There are 82 healthcare facilities in the public healthcare sector of Serbia for the treatment of infectious healthcare waste. District model is implemented and its provides a capacity for the treatment of 5.000 tones of infectious healthcare waste on annual basis. CTPs have been established mainly in general hospitals typically in the main town or city at a District level while LTPs have been established in remote health care facilities ( $\mathrm{HCFs}$ ). CTPs are provided with vehicles in order to collect and treat infectious waste from a number of HCF while LTP typically treat, in addition to their own waste, waste from only a limited number of HCFs.

In spite of a sound basis being established, until now the HCWM system has been fully developed although it is not rolled out on a country wide scale. Moreover, the current system does not address pharmaceutical and chemical HCRW in the most appropriate way since there is no capacity for the treatment of hazardous waste in the country (no incineration available). Furthermore, HCWM is not only an environmental issue but foremost an issue of occupational health and safety especially in relation to e.g. dialysis, laboratory and injection safety as well as an economic issue. Actually, two projects have shown that an integrated approach to HCWM can result in addressing and improving environmental, occupational health and safety, cost-reduction and clinical procedural aspects in one coordinated intervention. The second EU funded project addressed these issues particularly.

The current project shall therefore, while building on previous and ongoing initiatives and consolidating their results, enhance system implementation and further develop the HCWM system, including system instruments such as policy, legal and institutional frameworks and capacity. The project shall specifically address the issues of chemical and pharmaceutical waste management and occupational health and safety for laboratory operations and injections. Also the management of anatomical waste can be a cause of concern for aesthetic and cultural as well as occupational safety reasons. There are still issues to be improved especially regarding treatment on healthcare waste other than infectious waste. Further harmonization of the legal framework as well as guidance's for good practices in HCWM or the proper healthcare waste management in Serbia is going on and it is continues process supported by the second EU funded project called "Technical Assistance for Treatment of Healthcare waste management in Serbia". Serbian vision concerning improvement of HCWM includes further harmonization with EU legal framework on waste management and further improvement of HCWM based on EU directives and technical documents on good practices in this field.

Sustainability of the established HCWM system is provided by Program of General Interest on HCWM monitoring financed by the Ministry of Health, as well as by financing of health Insurance Fund for the costs of consumables for the collection of differrent streams of HCWM and for the treatment of infectious HCW.

Autoclave operators in 82 healthcare facilities are in the process of getting permanent job positions with the adequate job descriptions financed by Health Insurance Fund as well.

Technical recommandations for the HCWM are in place and they are implemented. The basis for the implementation of guidelines on HCWM is Serbian legal framework for HCWM. There is continual improvement process in the legal framework development in Serbia concerning HCWM which goes toward full acceptance of EU Directives on HCWM. 


\section{REFERENCES}

[1] APA (2010). Plano Estratégico dos Resíduos Hospitalares 2010-2016. Agência Portuguesa do Ambiente - Direcção Geral Saúde, Lisboa, Portugal.

[2] Botelho, A. (2012). "The impact of education and training on compliance behavior andwaste generation in European private healthcare facilities". Journal of EnvironmentalManagement, 98, 5 - 10.

[3] Manyele SV (2004a). "Effects of Improper Hospital Waste Management on Occupational Health and Safety", African Newsletter on Occupational Health and Safety 14: 30-33.
[4] Manyele SV, Anicetus H (2006). "Management of Medical Waste in Tanzanian Hospitals", Tanzania Health Res. Bull. 8(3): 177-182.

[5] Tosovic S, Jovanovic V at all (2008). Guideline for safe healthcare waste management, Belgrade.

[6] Pendić, Z., Jakovljević, B. i dr (2005), Primena HACCP koncepta pri izvršavanju medicinskih usluga, Istraživačka studija, Zavod za zdravstvenu zaštitu radnika JP Železnice Srbije \& EUROSYSTEMS, Septembar 2005

\section{REZIME}

\section{RAZVOJ UPRAVLJANJA MEDICINSKIM OTPADOM U SRBIJI I IZAZOVI ZA UNAPREĐENJE KVALITETA ZDRAVSTVENE ZAŠTITE}

Adekvatno upravljanje medicinskim otpadom (UMO) je uspostavljeno u Republici Srbiji u 2007. godini uz podršku Evropske unije. Od tada, količine tretiranog otpada, pre odlaganja na deponije, značajno su povećane $i$ sve više zdravstvenih ustanova usvaja adekvatan sistem UMO u svom radu. Paralelno sa razvojem UMO veliki broj zdravstvenih radnika je bio obučen za UMO. Ovo istraživanje prikazuje $i$ meri napredak koji je postignut.

Studija analizira period od 2009. do 2012. godine koristeći tri metoda prukupljanja podataka.

Na osnovu prikupljenih podataka, utvrđeno je da za populaciju od preko 7 miliona stanovnika, Srbija generiše između 4.500 i 5.000 tona infektivnog otpada godišnje, od čega $20 \%$ nastaje iz ambulantne zdravstvene zaštite, $75 \%$ potiče iz bolničke zdravstvene zaštite, dok $5 \%$ potiče od mikrobioloških laboratorijskih testova.

Tokom 2009. godine jedna trećina ove vrste otpada je bila tretirana pre odlaganja, dok je u 2011. godini ova količina porasla na dve trećine. Podaci takođe pokazuju da je više od $90 \%$ zdravstvenih ustanova definisalo sopstvene planove za upravljanje otpadom dok je u 2009. godini samo $20 \%$ ustanova imalo ovakvu praksu. U svakoj zdravstvenoj ustanovi postoje najmanje dve osobe obučene za upravljanje medicinskim otpadom, a ukupno oko 3.000 zaposlenih u zdravstvenim ustanovama završilo je zvaničnu obuku za UMO preko Instituta za javno zdravlje Srbije.

Upravljanje medicinskim otpadom se kontinuirano unapređuje u Republici Srbiji i dobro uspostavljen sistem upravljanja medicinskim otpadom postoji u oko $85 \%$ zdravstvenih ustanova. Postoje aspekti ovog procesa koji zahtevaju dalje unapređenje, posebno oni koji se tiču tokova medicinskog otpada isključujući infeketivni otpad.

Ključne reči: zdravstvena zaštita, upravljanje medicinskim otpadom,infektivni medicinski otpad 